\title{
AKTIVITAS ANTIPROLIFERASI ISOLAT 4 EKSTRAK PETROLEUM ETER DAUN Phaleria macrocarpa (Scheff.) Boerl. PADA SEL KANKER SERVIKS MANUSIA (HeLa)
}

\author{
Dwi Utami \\ Fakultas Farmasi Universitas Ahmad Dahlan Yogyakarta \\ email: utamipurwantoro@yahoo.com
}

\begin{abstract}
ABSTRAK
Kanker serviks merupakan penyebab kematian kedua wanita di Indonesia setelah kanker payudara. Mahkota dewa Phaleria macrocarpa (Scheff.) Boerl telah dikenal oleh masyarakat dan digunakan secara tradisional untuk pengobatan kanker. Ekstrak petroleum eter daun mahkota dewa menunjukkan aktivitas antiproliferasi pada sel kanker serviks manusia (HeLa) dengan $\mathrm{IC}_{50} 9 \mu \mathrm{g} / \mathrm{ml}$ (Kintoko dan Hawariah, 2007). Tujuan penelitian ini untuk mengetahui aktivitas antiproliferasi isolat 4 ekstrak petroleum eter terhadap sel kanker serviks manusia (HeLa).

Serbuk daun mahkota dewa disokletasi dengan petroleum eter, kemudian difraksi dengan etil asetat hingga diperoleh fraksi etil asetat. Fraksi etil asetat dilakukan kromatografi preparatif dengan fase gerak heksana : etil asetat (9:1). Aktivitas antiproliferasi terhadap sel HeLa ditetapkan harga $L C_{50}$ dan doubling time melalui uji sitotoksik dan pengamatan kinetika proliferasi dengan metode MTT.

Hasil isolasi dengan kromatografi preparatif diperoleh lima isolat masing-masing dengan harga $\mathrm{Rf}: 0,05 ; 0,10 ; 0,20 ; 0,60$; dan 0,90 . Harga $L C_{50}$ dari isolat 4 adalah sebesar $82,091 \mu \mathrm{g} / \mathrm{ml}$. Isolat 4 menunjukkan penghambatan pertumbuhan sel HeLa dengan memperpanjang doubling time (16,495 jam) dibanding kontrol sel (10,170 jam).
\end{abstract}

Kata kunci: Isolat 4, Phaleria macrocarpa (Scheff.) Boerl, antiproliferasi, sel HeLa, petroleum eter.

\section{ANTIPROLIFERATIV ACTIVITY OF ISOLATE 4 OF PETROLEUM ETHER EXTRACT OF Phaleria macrocarpa (Scheff.) Boerl. LEAVES TO HUMAN CERVICAL CANCER CELL LINES (Hela)}

\begin{abstract}
Cervical cancer is a malignant tumor in cervix which is occupy the second possition that cause the death of Indonesia's women under the breast cancer. One of the traditional medicine that can be used to cure cancer is Phaleria macrocarpa (Scheff.) Boerl leaves. The petroleum eter extract of mahkota dewa leaves has antiproliferation activity againts cervical cancer cell lines (HeLa) with $\mathrm{IC}_{50} 9 \mu \mathrm{g} / \mathrm{ml}$ (Kintoko and Hawariah, 2007). This research was aimed to detect antiproliferative activity of isolate 4 of ethyl acetate fraction of petroleum ether extract Phaleria macrocarpa (Scheff.) Boerl leaves againts HeLa cell lines.

Initially, the powder of Phaleria macrocarpa (Scheff.) Boerl was extracted using Soxhlet apparatus with petroleum ether. The extracts was concentrated and partitioned until ethyl acetate fraction was obtained. The fraction of ethyl acetate was isolated using
\end{abstract}


Preparative Thin Layer Chromatography on silica gel $\mathrm{F}_{254}$ as stationary phase and n-hexane : ethyl acetate $(9: 1)$ as mobile phase. Antiproliferation activity against HeLa cell lines was determinated by $\mathrm{LC}_{50}$ value by direct counting and doubling time value by MTT method.

The isolation by preparative thin layer chromatography resulted five isolate on $\mathrm{Rf}$ value: $0.05 ; 0.10 ; 0.20 ; 0.60$; and 0.90 . The $\mathrm{LC}_{50}$ values of isolate 4 was 82.091 $\mu \mathrm{g} / \mathrm{ml}$. Isolate 4 showed cell cycle delay at concentration $45 \mu \mathrm{g} / \mathrm{ml}$ by lenghthening the doubling time (16.495 hour) than cell control (10.170 hour).

\section{Key words : Isolate 4, Phaleria macrocarpa (Scheff.) Boerl, antiproliferation, HeLa cell, petroleum ether}

\section{PENDAHULUAN}

Kanker merupakan penyakit degeneratif yang dicirikan dengan keadaan sel yang tumbuh secara terus menerus tanpa kontrol dan mempunyai kemampuan untuk menyebar (bermetastasis) ke jaringan lain secara patologi (Hawariah, 1998). Kanker menjadi masalah utama kesehatan di seluruh dunia dan merupakan penyakit pembunuh terbesar kedua setelah kardiovaskuler. Menurut laporan WHO tahun 2002, terdapat lebih dari 10 juta kasus kanker per tahun di dunia (Surh, 2003). Sedangkan di Indonesia penyakit kanker menjadi penyebab kematian keenam (Siswono, 2005). Dari tahun ke tahun penderita penyakit kanker jumlahnya terus meningkat termasuk di Indonesia dimana peningkatannya mencapai 190 ribu penderita kanker baru per tahun (Mariono dkk., 2002).

Di antara jenis kanker pada wanita, kanker leher rahim (serviks) merupakan jenis kanker maligna yang paling sering menyerang wanita, khususnya di negara-negara berkembang (Cronje, 2004) dengan jumlah penderita sebanyak 40 orang setiap 100.000 orang. Sedangkan di Indonesia diperkirakan jumlah pengidap kanker serviks antara 25-40 orang penderita setiap 100.000 orang per tahun (A. de Boer dkk, 2004).

Terapi konvensional yang umum dilakukan pada penyakit kanker serviks antara lain dengan pembedahan, kemoterapi dan radioterapi (Apantaku, 2002). Namun terapi pembedahan tidak dapat dilakukan khususnya pada sel kanker yang telah menyebar (metastasis), sedangkan kemoterapi dan radiasi dapat menimbulkan efek samping meskipun kemoterapi mampu mengeluarkan keseluruhan sel-sel tumor (Hawariah, 1998).

Kegagalan dalam kemoterapi ini biasanya berkaitan dengan kegagalan agen antikanker tersebut untuk menginduksi kematian sel kanker secara terprogram (apoptosis) (Fisher,1994). Karena itu, usaha pencarian agen kemoterapi baru yang mampu menginduksi kematian sel kanker secara apoptosis dengan memberikan efek samping minimum adalah sangat diperlukan dalam terapi kanker serviks, yaitu dengan mengembangkan senyawa dari bahan alami sebagai agen kemoterapi.

Mahkota dewa telah dikenal oleh masyarakat dan digunakan secara tradisional untuk pengobatan kanker. Hasil penelitian sebelumnya menunjukkan ekstrak petroleum eter daun mahkota dewa menunjukkan aktivitas antiproliferasi pada sel kanker serviks manusia (HeLa) dengan $\mathrm{IC}_{50}$ $9 \mu \mathrm{g} / \mathrm{ml}$ (Kintoko dan Hawariah, 2007). Fraksi etil asetat ekstrak petroleum eter daun mahkota dewa mempunyai aktivitas sitotoksik terhadap sel HeLa 
dengan nilai $\mathrm{IC}_{50} 25,409 \mu \mathrm{g} / \mathrm{mL}$ (Sahara, 2010). Fraksi kloroform ekstrak petroleum eter daun mahkota dewa mempunyai aktivitas sitotoksik terhadap sel HeLa dengan nilai $\mathrm{IC}_{50} 71,83 \mu \mathrm{g} / \mathrm{mL}$ (Kurniawati, 2010). Fraksi n-heksan ekstrak petroleum eter daun mahkota dewa mempunyai aktivitas sitotoksik terhadap sel HeLa dengan nilai $\mathrm{IC}_{50}$ 209,196 $\mu \mathrm{g} / \mathrm{mL}$ (Maulida, 2010). Fraksi metanol-air ekstrak petroleum eter daun mahkota dewa mempunyai aktivitas sitotoksik terhadap sel HeLa dengan nilai $\mathrm{IC}_{50} 431,635 \mu \mathrm{g} / \mathrm{mL}$ (Pratama, 2010).

Target utama terapi kanker
secara umum adalah menghambat pertumbuhan sel kanker tersebut melalui induksi proses kematian sel secara apoptosis. Karena itu, diperlukan penelitian lanjut untuk mengisolasi komponen aktif dalam ekstrak petroleum eter daun mahkota dewa dan menguji aktivitas antiproliferasi pada sel kanker serviks manusia (HeLa).

\section{METODE PENELITIAN}

\section{Alat dan Bahan}

Alat-alat yang digunakan adalah timbangan analitik, gelas ukur, gelas beker, alat sokhlet, kertas saring, vaccum rota evaporator, penangas air, cawan porselin, pengaduk, plastik, karet pengikat, dan almari es, corong pisah, corong buchner, flakon dan kertas saring, autoclave, incubator $\mathrm{CO}_{2}$, lampu $\mathrm{UV}$, laminar air flow cabinet, tissue culture flask, tabung conical, microplate 96 sumuran, haemocytometer, microplate 24 sumuran (Nunclone), tissue culture flask (Nunclone), neraca elektrik (Sartorius), mikropipet (Gilson), cover slip, cover glass, mikroskop fluoresense, cell counter, ELISA reader, magnetic stirrer, mikroskop, pipet, neraca analitik, kamera digital, dan lemari es.

Bahan utama penelitian ini adalah serbuk kering daun mahkota dewa. Sedangkan bahan kimia yang diperlukan seperti pelarut untuk ekstraksi, fraksinasi, dan isolasi adalah petroleum eter, etil asetat derajat teknis dan pro analysis, aquadest dan silika gel $\mathrm{F}_{254}$ yang diperoleh dari Laboratorium Farmakognosi Fitokimia UAD. Sel HeLa, sel Vero, media DMEM (Dulbecco's modification of Eagle medium), DMSO, PBS (Phospat Buffered Saline), PenisillinStreptomisin 2\%, Fungison 0,5\%, FBS (Fetal bovine serum) 10\%, TrypsinEDTA 0,25\% dalam PBS, SDS (Sodium dodecyl sulfat) $10 \%$ dalam $\mathrm{HCl} 0,01 \mathrm{~N}$, $\mathrm{NaHCO}_{3}$ teknis dan HEPES (N-2-hydroxyethil piperazin-N-2ethane sulfonic acid) teknis, dan tripan blue.

\section{Prosedur Penelitian}

\section{Identifikasi Daun Mahkota Dewa (Phaleria macrocarpa (Scheff) Boerl)}

Tanaman Daun Mahkota Dewa (Phaleria macrocarpa (Scheff) Boerl) yang akan digunakan dalam penelitian ini terlebih dahulu dilakukan identifikasi untuk memastikan kebenarannya. Identifikasi dilakukan di Laboratorium Biologi Farmasi Fakultas Farmasi Universitas Gadjah Mada Yogyakarta.

\section{Pengumpulan bahan}

Pengambilan bahan uji daun mahkota dewa dilakukan pada bulan Maret tahun 2010 di Wates, Yogyakarta. Dalam penelitian ini digunakan daun yang masih segar dan tidak rusak. Persiapan sebelum bahan digunakan adalah daun dibersihkan dengan menggunakan air bersih yang mengalir untuk menghilangkan kotoran-kotoran yang ada. Setelah itu dilakukan pengeringan dengan menggunakan oven dengan suhu $50^{\circ} \mathrm{C}$ sampai daun mahkota 
dewa benar-benar kering. Setelah daun mahkota dewa kering maka dilakukan penyerbukan.

\section{Pembuatan ekstrak petroleum eter daun mahkota dewa (Phaleria macrocarpa (Scheff) Boerl)}

Serbuk daun mahkota dewa seberat 500 gram disari dengan alat Soxhlet menggunakan pelarut petroleum eter. Pelarut yang digunakan adalah $2 \mathrm{x}$ sirkulasi dengan kecepatan sirkulasi 6-8 sirkulasi/jam. Pembuatan ekstrak kental dengan Soxhlet ini dilakukan sampai zat aktif yang terdapat dalam daun mahkota dewa habis. Apabila zat aktif habis ditandai dengan jernihnya pelarut yang digunakan. Apabila filtrat telah didapatkan maka filtrat dimasukkan ke dalam vaccum rota evaporator kemudian diuapkan pelarutnya sampai pelarutnya tidak menetes lagi. Penggunaan vaccum rota evaporator pada suhu $60-70{ }^{\circ} \mathrm{C}$ dan 1,5 putaran. Ekstrak kental yang diperoleh ditimbang dan dihitung rendemennya.

\section{Pembuatan fraksi etil asetat daun mahkota dewa (Phaleria macrocarpa (Scheff) Boerl)}

Ekstrak kental yang diperoleh dilarutkan dalam etil asetat kemudian dilakukan fraksinasi dengan air, kemudian digojog di dalam corong pisah lalu didiamkan selama 24 jam agar fraksi etil asetat dan fraksi air terpisah sempurna. Setelah didiamkan selama 24 jam fraksi air beserta endapan-endapan yang ada didalamnya dikeluarkan. Hasil fraksi etil asetat disaring menggunakan corong buchner agar penyaringan lebih sempurna dan endapan yang ada didalamya benar-benar terpisahkan. Fraksi etil asetat yang didapat disimpan di lemari es.

\section{Pembuatan isolat dari fraksi etil asetat daun mahkota dewa (Phaleria macrocarpa (Scheff) Boerl)}

Fraksi etil asetat yang diperoleh sebanyak 448,5 ml, dipekatkan di lemari asam hingga, kemudian diambil dengan pipa kapiler secukupnya dan dibuat pita diatas plate KLT hingga semua fraksi habis. Kemudian ditunggu beberapa saat sampai pita kering. Setelah itu dimasukkan ke chamber yang sudah diberi fase gerak berupa heksan : etil asetat (9:1). Elusi sampai batas yang telah ditentukan. Apabila elusi telah selesai dilakukan, maka segera dikeringkan kaca di suhu kamar. Silica gel 60 GF 254 dikerok sesuai isolat yang diinginkan. Isolat tersebut digunakan untuk uji sitotoksik terhadap sel HeLa. Isolat dimurnikan kembali dengan kromatografi Vakum Cair dengan fase gerak kloroform : methanol (1:1)

\section{Uji Aktivitas Sitotoksik}

Sebelum dilakukan uji sitotoksisitas, terlebih dahulu dibuat larutan stok sampel dengan cara mencampur isolat fraksi etil asetat daun mahkota dewa dengan media DMEM. Larutan stok dibuat dengan cara menimbang isolat fraksi etil asetat daun mahkota dewa kemudian ditambah DMSO atau tween sebanyak $30 \mu l$ dan ditambahkan dengan media DMEM hingga $1000 \mu \mathrm{l}$, sehingga konsentrasi tertentu, dari konsentrasi larutan tersebut kemudian dibuat seri kadar dan larutan dalam berbagai kadar tersebut dapat diujikan pada sel HeLa. Pembuatan larutan uji ini dilakukan di dalam Laminar Air Flow Cabinet secara aseptis.

Sel dengan kepadatan $1 \times 10^{4}$ sel/100 $\mu 1$ didistribusikan ke dalam sumuran dan diinkubasi bersama isolat fraksi etil asetat ekstrak petroleum eter daun mahkota dewa dengan 6 kadar berbeda $750 ; 375 ; 187,5 ; 93,75 ; 46,88$ dan $23,49 \quad \mu \mathrm{g} / \mathrm{ml}$. Selanjutnya microplate diinkubasi dalam inkubator $\mathrm{CO}_{2} 5 \%$, pada suhu $37^{\circ} \mathrm{C}$ selama 24 jam. Setelah itu media dalam sumuran di 
sedot habis kemudian ditambahkan tripsin-EDTA sebanyak $100 \mu 1$ dan dilakukan resupensi berlahan-lahan. Setelah didiamkan 3 menit dilakukan penambahan larutan tripan blue sebanyak $100 \mu \mathrm{l}$. Penghitungan jumlah sel hidup dilakukan langsung pada haemocytometer.

Sebelum

haemocytometer sebagai media penghitung sel, harus dilakukan pembersihan haemocytometer dan objek glass menggunakan alkohol $70 \%$. Setelah itu ambil $10 \mu 1$ larutan suspensi yang telah ditambahkan tripan blue menggunakan pipet pasteur dan dimasukkan kedalam chamber haemocytometer. Sel yang bewarna biru menandakan sel tersebut mati, sedangakan sel yang bewarna bening menandakan sel tersebut masih hidup (Doyle and Griffiths, 2000).

\section{Uji kinetika proliferasi dengan metode MTT}

Sel distarvasi (dipuasakan) selama 24 jam dalam media kultur yang mengandung FBS 0,5\%. Selanjutnya sel ditumbuhkan di dalam plate 96 sumuran (multiple dishes) dengan medium ditambah sampel dengan konsentrasi yang tidak mematikan (dibawah nilai $I C_{50}$ ), sampling dilakukan pada jam 24 , 48 dan 72. Masing-masing sumuran dihitung jumlah sel yang hidup dengan metode MTT dan dibuat kurva absorbansi $v s$ waktu inkubasi.

\section{HASIL DAN PEMBAHASAN}

Hasil determinasi, identifikasi makroskopis dan mikroskopis menunjukkan bahwa tanaman yang digunakan dalam penelitian ini adalah mahkota dewa (Phaleria macrocarpa (Scheff.) Boerl).

Serbuk daun mahkota dewa disohkletasi dengan petroleum untuk memperoleh ekstrak petroleum eter, selanjutnya ekstrak petroleum eter dilakukan fraksinasi cair-cair menghasilkan fraksi etil asetat. Fraksi etil asetat yang telah diperoleh kemudian dilakukan isolasi dengan menngunakan KLT-preparatif dengan fase diam silica gel $\mathrm{GF}_{254}$ dan fase gerak heksana : etil asetat $(9: 1)$ berdasarkan hasil orientasi fase gerak yang menghasilkan spot paling banyak.

Tahap purifikasi untuk menghasilkan isolat dilakukan dengan KLT preparatif, dengan cara menotolkan bentuk pita dari fraksi etil asetat pada lempeng $20 \times 20 \mathrm{~cm}$ yang telah dilapisi silica gel $\mathrm{GF}_{254}$ dan dielusi dalam bejana kromatografi dengan fase gerak heksana : etil asetat $(9: 1)$. Hasil KLT preparatif menunjukkan adanya 5 pita seperti terlihat pada Gambar 1. Pita 1 dengan harga $\mathrm{Rf}$ : 0,05 selanjutnya disebut sebagai isolat 1 , pita 2 dengan harga Rf : 0,10 (isolat 2), pita 3 dengan harga Rf : 0,20 (isolat 3), pita 4 dengan harga $\mathrm{Rf}: 0,60$ (isolat 4) dan terakhir pita 5 dengan harga $\mathrm{Rf}$ : 0,90 disebut sebagai isolat 5 .

Isolat 4 yang diperoleh sebanyak 25,3 mg. Tahapan selanjutnya dari penelitian ini adalah uji aktivitas antiproliferatif dari isolat 4. Seri kadar isolat uji terhadap sel HeLa adalah 750; $375 ; 187,5 ; 93,75 ; 46,88$ dan 23,49 $\mu \mathrm{g} / \mathrm{ml}$. Berdasarkan Tabel 3 dan grafik hubungan konsentrasi dengan $\%$ kematian sel (Gambar 2) terlihat bahwa isolat 4 menunjukkan bersifat toksik terhadap sel HeLa yang berbanding lurus dengan kenaikan konsentrasi. Parameter yang digunakan untuk mengevaluasi potensi ketoksikan senyawa uji terhadap sel HeLa adalah $L C_{50}$. Perhitungan $L C_{50}$ menggunakan analisis probit berdasarkan pada grafik fungsi linear log konsentrasi vs nilai probit dari \% kematian akibat pemberian zat uji. Harga $L C_{50}$ diperoleh dengan memasukkan probit-5 ke dalam 
persamaan garis lurus tersebut. Berdasarkan harga $\mathrm{LC}_{50}$, terlihat bahwa isolat 4 memiliki aktivitas sitotoksik tertinggi terhadap sel HeLa dengan harga $L C_{50} 82,091 \mu \mathrm{g} / \mathrm{mL}$.

Aktivitas antiproliferasi isolat diuji dengan pengamatan kinetika proliferasi pada waktu 24,48 dan 72 jam dengan metode MTT guna melihat jumlah sel yang setara dengan absorbansi. Gambar 3 menunjukkan pada kontrol sel absorbansi (jumlah sel hidup) mengalami kenaikan. Semakin lama waktu inkubasi maka semakin meningkat pula jumlah sel yang hidup.
Pada perlakuan sediaan uji terjadi kenaikan jumlah sel yang sangat pesat pada jam ke-24, diduga sel mengalami lag time atau fase adaptasi. Pada jam ke48 perlakuan sediaan uji mengalami peningkatan tetapi pada jam ke-72 kembali menurun. Hal ini dapat disebabkan karena sel mengalami kematian. Kematian ini dapat melalui mekanisme arrest (siklus sel berhenti) dulu baru mengalami apoptosis atau langsung mengalami apoptosis. Dengan terhentinya siklus sel maka sel tidak dapat menggandakan dirinya.
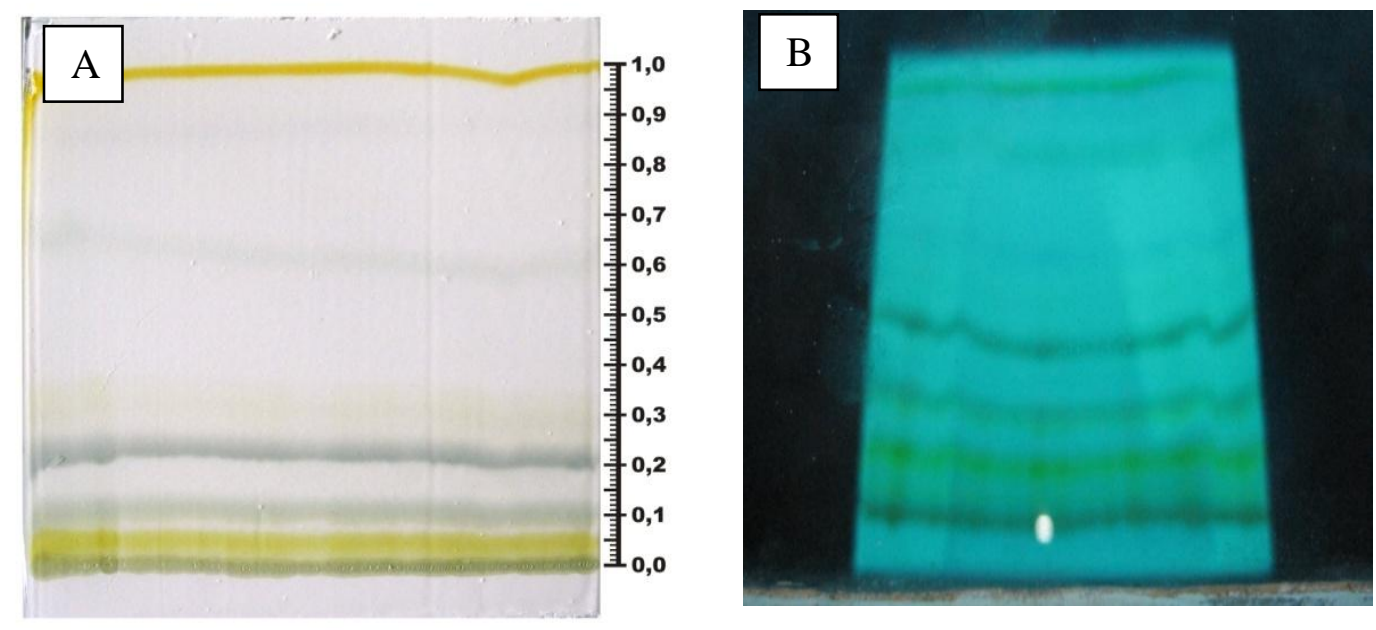

Gambar 1. Profil KLT preparatif fraksi etil asetat ekstrak petroleum eter daun mahkota dewa (Phaleria macrocarpa)

Fase diam : Silika gel $\mathrm{GF}_{254}$, Fase gerak heksana-etil asetat (9:1)

A. Sinar tampak

B. Dibawah sinar UV $254 \mathrm{~nm}$

Tabel 1. Hasil KLT preparatif Fraksi Etil Asetat

\begin{tabular}{llll}
\hline Nama Bercak & Harga Rf & \multicolumn{2}{c}{ Detektor } \\
\cline { 3 - 4 } & & \multicolumn{1}{c}{ Visual } & \multicolumn{1}{c}{$254 \mathrm{~nm}$} \\
\hline Isolat 1 & 0,05 & Kuning & Tidak Fluoresensi biru \\
Isolat 2 & 0,10 & Biru muda & Fluoresensi biru lemah \\
Isolat 3 & 0,20 & Biru muda & Fluoresensi biru lemah \\
Isolat 4 & 0,60 & Biru & Fluoresensi biru \\
Isolat 5 & 0,90 & Biru tua & Fluoresensi biru \\
\hline
\end{tabular}


Aktivitas antiproliferasi isolat 4 ekstrak petroleum eter... (Dwi Utami)

Tabel 2. Pengaruh konsentrasi isolat 4 pada kematian sel (\%) sel HeLa.

\begin{tabular}{|c|c|}
\hline Konsentrasi $(\mu \mathrm{g} / \mathrm{ml})$ & \% kematian sel \\
\hline 750 & $98,476 \pm 0,09$ \\
\hline 375 & $100,653 \pm 1,11$ \\
\hline 187,5 & $91,726 \pm 2,42$ \\
\hline 93,75 & $54.491 \pm 3,18$ \\
\hline 46,88 & $18,236 \pm 3,28$ \\
\hline 23,49 & $11,813 \pm 8,02$ \\
\hline
\end{tabular}

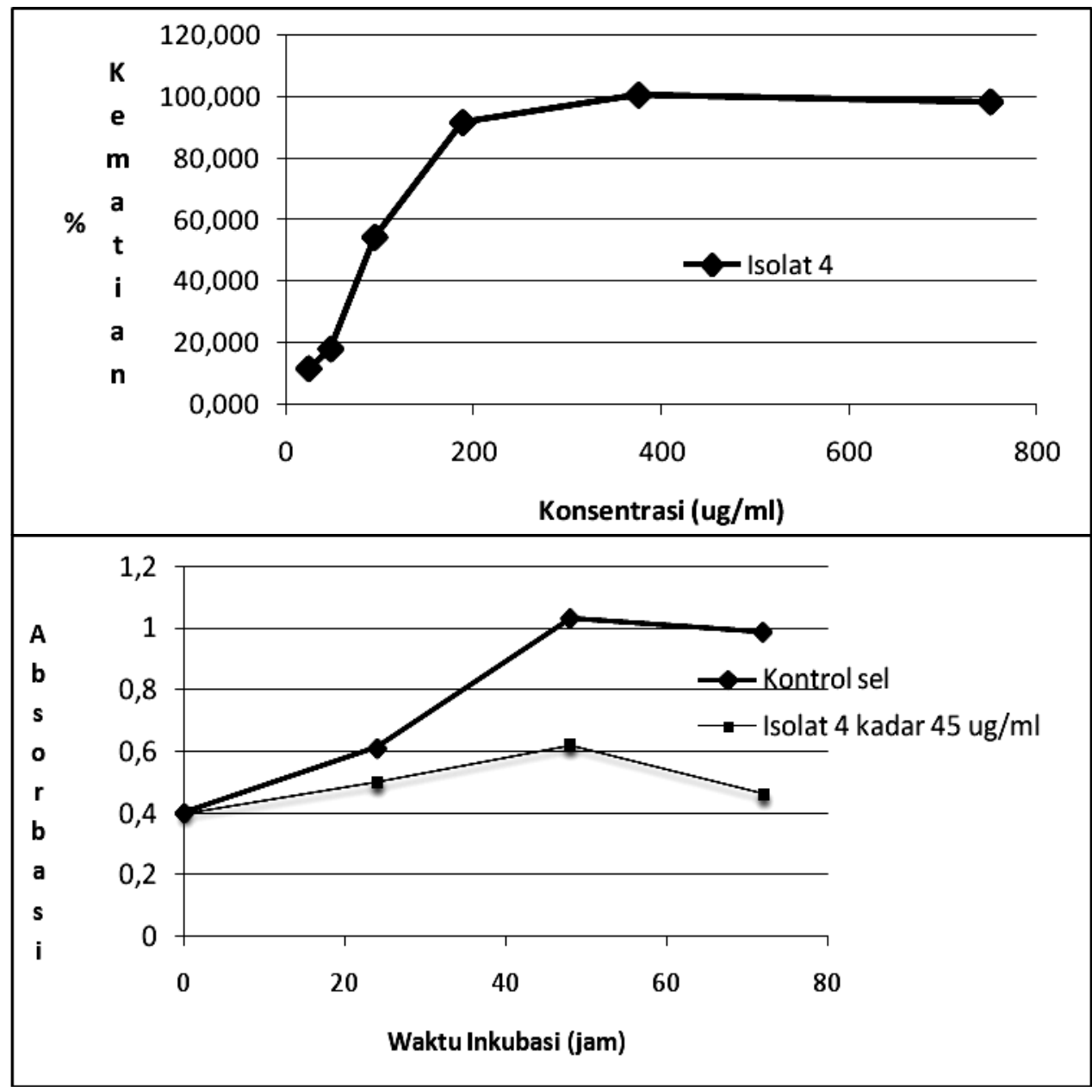

(A)

(B)

Gambar 2. Grafik hubungan konsentrasi isolat $4(\mu \mathrm{g} / \mathrm{ml})$ terhadap prosentase kematian sel HeLa (A) dan kinetika proliferasi sel HeLa dibandingkan terhadap kontrol (B)

Tabel 4. Persamaan grafik log jumlah sel hidup vs waktu pada kinetika proliferasi sel HeLa dengan berbagai perlakuan

\begin{tabular}{|c|c|c|c|c|}
\hline Perlakuan & Persamaan garis & Slope & Linearitas & $\begin{array}{c}\text { Doubling time } \\
\text { (jam) }\end{array}$ \\
\hline Kontrol & $\mathrm{Y}=0,02430 \mathrm{x}+3,8041$ & 0,02430 & 0,9875 & 10,170 \\
\hline Isolat 4 & $\mathrm{Y}=0,0159 \mathrm{x}+3,7892$ & 0,0159 & 0,9848 & 16,495 \\
\hline
\end{tabular}


Sifat antiproliferasi ditunjukkan dengan nilai doubling time yang lebih besar dibandingkan dengan kontrol sel. Pada penelitian ini nilai doubling time kontrol sel lebih kecil dibanding perlakuan. Pada kontrol sel diperoleh doubling time 10,170 jam dan doubling time sediaan uji isolat 4 dengan harga 16,495 jam. Hal ini menandakan bahwa isolat 4 memiliki kemampuan menghambat proliferasi sel HeLa melalui penghambatan doubling time.

Mekanisme penghambatan proliferasi kemungkinan melalui protein-protein pengatur proliferasi dan apoptosis seperti up-regulasi protein pro apoptosis Bax dan mengiduksi aktivitas caspase-caspase sebagai mesin penggerak program apoptosis (Faried dkk), selain itu juga menurunkan regulasi protein anti apoptosis $\mathrm{Bcl}-2$ dan Xiap. Ataupun melalui pembentukkan fragmentasi DNA, penurunan ekspresi Bcl mRNA dan kenaikkan ekspresi Bax mRNA (Tjandrawinata dkk, 2009).

\section{KESIMPULAN DAN SARAN}

\section{A. Kesimpulan}

1. Isolasi fraksi etil asetat ekstrak petroleum eter daun mahkota dewa (Phaleria macrocarpa (Scheff.) Boerl)dengan metode kromatografi lapis tipis preparatif fase gerak heksana : etil asetat (9: 1) menghasilkan 5 isolat yang belum terpurifikasi.

2. Aktivitas sitotoksik isolat 4 fraksi etil asetat ekstrak petroleum eter daun mahkota dewa (Phaleria macrocarpa (Scheff.) Boerl) adalah sebesar 82,091 $\mu \mathrm{g} / \mathrm{ml}\left(\mathrm{LC}_{50}\right)$

3. Isolat 4 fraksi etil asetat ekstrak petroleum eter daun mahkota dewa (Phaleria macrocarpa (Scheff.) Boerl) mampu menghambat proliferasi sel HeLa dengan memperpanjang doubling time pada kadar $45 \mu \mathrm{g} / \mathrm{ml}$.

\section{B. Saran}

1. Perlu dilakukan pemurnian lebih lanjut terhadap isolat hasil KLT preparatif, dengan kromatografi kolom ataupun HPLC.

2. Perlu dilakukan purifikasi lebih lanjut terhadap isolat 4 yang memiliki aktivitas antiproliferasi tertinggi terhadap pertumbuhan sel HeLa.

3. Perlu dikaji lebih lanjut mekanisme penghambatan pertumbuhan sel HeLa secara molekuler melalui uji imunositokimia terhadap enzim, protein ataupun gen yang berperan dalam proliferasi ataupun apoptosis.

\section{DAFTAR PUSTAKA}

A.de Boer, M., A.W. Peter, L., Aziz, M.F., Siregar, B., Cornain, S., Vrede,M.A., S. Jordanova, E., Uljee, S.K. and Fleuren, G.J., 2004, Human papilomavirus type 16 E6, E7 and L1 variant in cervical cancer in Indonesia, Suriname, Netherland, Gyn. Oncol. Vol.94, 488-494.

Apantaku, L.M., 2002, Breast-conseving surgery for breast cancer, Am.Fam.Physician, Vol.66, No.12, 2271-2278.

Hawariah, L.P., 1998, Kanker Payudara, Penerbit universiti Putra Malaysia, Serdang.

Cronje, H.S. 2004. Screening of cervical cancer in developing countries. Int. J. Gyn and Obst, Vol.84, 101-108.

Faried, A., Kurnia, D., Faried, L. S., Usman, N., Miyazaki, T., Kato, H., Kuwano, H., 2006, Anticancer Effects of Gallic Acid 
Isolated from Indonesian Herbal Medicine, Phaleria macrocarpa (Scheff.) Boerl, on Human Cancer Cell Lines : International Journal of Oncology, Padjadjaran University Faculty of Medicine, Bandung.

Fisher, D.E., 1994, Apoptosis in cancer therapy: crossing the threshold, Cell, Vol.78, No.4, 539-542.

Kurniawati,Anisa, 2010, Sitotoksisitas Fraksi Kloroform Ekstrak Petroleum Eter Daun Mahkota Dewa ( Phaleria Macrocarpa (Scheff.) Boerl ) terhadap Sel HeLa dan Sel Vero beserta Profil Kromatografinya, Skripsi, Universitas Ahmad Dahlan, Yogyakarta.

Kintoko dan Hawariah, 2007, Antiproliferative effect of extract of mahkota dewa [Phaleria macrocarpa (Scheff). Boerl.] on selected cancer cell line and its mode of cell death, Proceeding of the $1^{\text {st }}$ International Conference on Chemical Science, 229-231.

Mariono, S.A., Jusuf, A., Kresno, S.B., 2002, Karakteristik kandungan DNA dan aktivitas proliferasi pada kanker paru di Jakarta, Cermin Dunia Kedokteran, Vol.127, 15-17.

Maulida, Nisa, A., 2010, Sitotoksisitas Fraksi n-Heksan Ekstrak Petroleum Eter Daun Mahkota Dewa (Phaleria Macrocarpa (Scheff.) Boerl ) terhadap Sel HeLa dan Sel Vero beserta Profil Kromatografinya, Skripsi, Universitas Ahmad Dahlan, Yogyakarta.
Pratama, Anton, 2010, Sitotoksisitas Fraksi Metanol-Air Ekstrak Petroleum Eter Daun Mahkota Dewa (Phaleria Macrocarpa (Scheff.) Boerl) terhadap Sel HeLa dan Sel Vero beserta Profil Kromatografinya, Skripsi, Universitas Ahmad Dahlan, Yogyakarta.

Sahara, Nasa Milta, 2010, Uji Sitotoksisitas Fraksi Etil Asetat Ekstrak Petroleum Eter Daun Mahkota Dewa (Phaleria Macrocarpa (Scheff.) Boerl) terhadap Sel HeLa dan Sel Vero beserta Profil Kromatografinya, Skripsi, Universitas Ahmad Dahlan, Yogyakarta.

Siswono, 2005, Setiap tahun 190 ribu penderita kanker baru, http://www.gizi.net diakses 12 November 2006.

Surh, Y.J., 2003, Cancer Chemoprevention with Dietary Phytochemicals, Nature Reviews Cancer, Vol 3, $768-780$.

Tjandrawinata RR, Arifin PF, Tandrasasmita OM, Rahmi D, Aripin A, 2010, DLBS1425, a Phaleria macrocarpa (Scheff.) Boerl. extract confers anti proliferative and proapoptosis effects via eicosanoid pathway, J. Ther. Oncol, Vol.3, 187-201. 